\title{
Opioid Signal Transduction in Intact and Fragmented SH-SY5Y Neural Cells
}

\author{
Bruce D. Carter and Fedor Medzihradsky \\ Departments of Biological Chemistry and Pharmacology, The University of Michigan Medical School, \\ Ann Arbor, Michigan, U.S.A.
}

\begin{abstract}
Parameters of ligand binding, stimulation of low$K_{\mathrm{m}}$ GTPase, and inhibition of adenylate cyclase were determined in intact human neuroblastoma SH-SY5Y cells and in their isolated membranes, both suspended in identical physiological buffer medium. In cells, the $\mu$-selective opioid agonist $\left[{ }^{3} \mathrm{H}\right]$ Tyr-D-Ala-Gly(Me)Phe-Gly-ol $\left(\left[{ }^{3} \mathrm{H}\right] \mathrm{DAMGO}\right)$ bound to two populations of sites with $K_{\mathrm{D}}$ values of 3.9 and $160 \mathrm{nM}$, with $<10 \%$ of the sites in the high-affinity state. Both sites were also detected at $4^{\circ} \mathrm{C}$ and were displaced by various opioids, including quaternary naltrexone. The opioid antagonist $\left[{ }^{3} \mathrm{H}\right]$ naltrexone bound to a single population of sites, and in cells treated with pertussis toxin the biphasic displacement of $\left[{ }^{3} \mathrm{H}\right]$ naltrexone by DAMGO became monophasic with only low-affinity binding present. The toxin specifically reduced high-affinity agonist binding but had no effect on the binding of $\left[{ }^{3} \mathrm{H}\right]$ naltrexone. In isolated membranes, both agonist and antagonist bound to a single population of receptor sites with affinities similar to that of the high-affinity binding component in cells. Addition of GTP to membranes reduced the $B_{\max }$ for $\left[{ }^{3} \mathrm{H}\right] \mathrm{DAMGO}$ by $87 \%$ and induced a linear ligand binding component; a low-affinity binding site, however, could not be saturated. Compared with results obtained with membranes suspended in Tris buffer, agonist
\end{abstract}

binding, including both receptor density and affinity, in the physiological medium was attenuated. The results suggest that high-affinity opioid agonist binding represents the ligandreceptor-guanine nucleotide binding protein ( $G$ protein) complex present in cells at low density due to modulation by endogenous GTP. Opioid receptor coupling to adenylate cyclase in intact and fragmented cells occurred with similar efficiency: DAMGO inhibited adenylate cyclase with $K_{\mathrm{i}}$ values of $11 \mathrm{n} M$ in cells and $26 \mathrm{n} M$ in lysates, with $30 \%$ maximal inhibition in both preparations. Receptor coupling to $G$ protein in membranes occurred with similar parameters: DAMGO stimulated low- $K_{\mathrm{m}}$ GTPase with a $K_{\mathrm{s}}$ of $31 \mathrm{n} M$ and an $S_{\max }$ of $48 \%$. Both effector responses were blocked by naloxone and were strongly impaired by rigorous cell homogenization. These results indicate that opioid signal transduction in intact SH-SY5Y cells and their appropriately isolated membranes functions with similar efficiencies involving a large reserve of uncoupled receptors. Key Words: $\mu$-Opioid receptor- $G$ protein-Adenylate cyclase-GTPase-SHSY5Y cells. Carter B. D. and Medzihradsky F. Opioid signal transduction in intact and fragmented SH-SY5Y neural cells. J. Neurochem. 58, 1611-1619 (1992).
Agonist binding to opioid receptor results in the inhibition of adenylate cyclase (Sharma et al., 1975; Law et al., 1981), is mediated by guanine nucleotide binding protein (G protein) (Burns et al., 1983; Kurose et al., 1983 ), and involves the stimulation of low- $K_{\mathrm{m}}$ GTPase (Koski and Klee, 1981; Barchfeld and Medzihradsky, 1984). The high- and low-affinity binding components of opioid agonists, in contrast to those of antagonists, have been identified as ligand complexes with $G$ protein-coupled and free receptors, respectively (Remmers and Medzihradsky, 1991 $a, b$ ). Although these receptor mechanisms are well established, diverging character- istics for individual steps were obtained in various systems, e.g., both monophasic and biphasic binding of opioid agonists has been described. Whereas the binding of $\left[{ }^{3} \mathrm{H}\right]$ Tyr-D-Ala-Gly-(Me)Phe-Gly-ol $\left(\left[{ }^{3} \mathrm{H}\right] \mathrm{DAMGO}\right)$ in membranes from brain (Werling et al., 1985) and SH-SY5Y cells (Kazmi and Mishra, 1987; Toll, 1990) and of $\left[{ }^{3} \mathrm{H}\right]$ etorphine in mouse pituitary tumor cells and NG108-15 neuroblastomaglioma hybrids (Puttfarcken et al., 1986) was monophasic, $\left[{ }^{3} \mathrm{H}\right]$ Tyr-D-Ala-Gly-Phe-D-Leu in NG108-15 cells (Costa et al., 1985) and $\left[{ }^{3} \mathrm{H}\right] D A M G O$ in SH-SY5Y cells (Fig. 1) bound to two populations of receptor sites.
Received May 2, 1991; revised manuscript received September 12, 1991; accepted September 30, 1991.

Address correspondence and reprint requests to Dr. F. Medzihradsky at Department of Biological Chemistry, The University of Michigan Medical School, Ann Arbor, MI 48109-0606, U.S.A.
Abbreviations used: cAMP, cyclic AMP; DAMGO, Tyr-D-Ala-Gly(Me)Phe-Gly-ol; G protein, guanine nucleotide binding protein. 


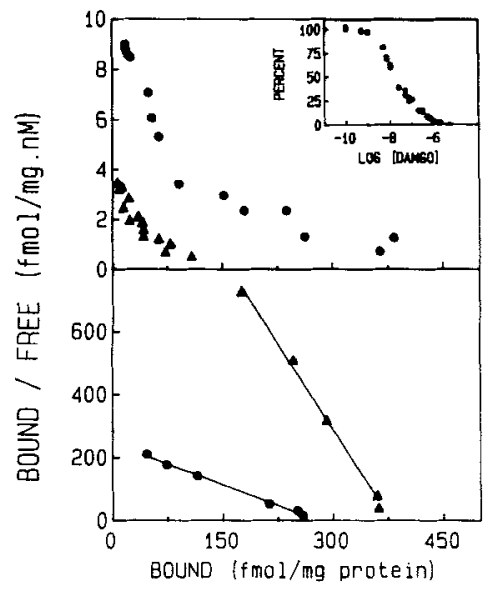

FIG. 1. Scatchard plots of opioid receptor binding in intact $\mathrm{SH}$ SY5Y cells. Results of homologous displacement of $\left[{ }^{3} \mathrm{H}\right] \mathrm{DAMGO}$ (upper panel) and saturation binding of $\left[{ }^{3} \mathrm{H}\right]$ naltrexone at equilibrium (lower panel) in physiological buffer at $37(0)$ and $4^{\circ} \mathrm{C}(\Delta)$ are shown. Inset: Homologous displacement data as the percentage of [ $\left.{ }^{3} \mathrm{H}\right] \mathrm{DAMGO}$ bound versus increasing concentrations of unlabeled DAMGO. Results of representative experiments replicated two to five times are shown. The corresponding binding parameters and statistical information are listed in Table 1.

It is particularly difficult to reconcile the differences in the kinetic parameters of opioid ligand-receptor-effector interactions obtained in isolated membranes and intact cells. For example, monophasic binding of $\left[{ }^{3} \mathrm{H}\right]$ Tyr-D-Ala-Gly-Phe-D-Leu was described in homogenates of NG108-15 hybrids (Costa et al., 1988), but biphasic interaction in the whole cells (Costa et al., 1985). Interpretation of opioid binding in intact cells is made difficult by possible ligand-receptor internalization (Blanchard et al., 1983), intracellular opioid receptors (Roth et al., 1981), and existence of nonopioid binding sites (Schweigerer et al., 1985).

Disparity between intact cells and isolated membranes has also been described for receptor-effector coupling: The $\mathrm{IC}_{50}$ for opioid inhibition of adenylate cyclase was higher in isolated membranes than in whole cells (see, e.g., Costa et al., 1988). The efficiency of opioid receptor-effector coupling, assessed by the ratio of ligand binding affinity to the extent of effector response, was different in various whole and fragmented cells, respectively: $K_{\mathrm{D}} / \mathrm{IC}_{50}$ ratios of 1 (Creese and Snyder, 1975; Carroll et al., 1988), <1 (Puttfarcken et al., 1986; Costa et al., 1988), and $>1$ (Law et al., 1983) were reported.

The above-outlined discrepancies in ligand binding and receptor coupling are largely unresolved and contribute to the existing gap in relating information obtained with isolated membranes to opioid function observed in intact cells or whole animals. The importance of comparing receptor mechanisms in whole and fragmented cells has also been recognized in other receptor systems, e.g., the adrenergic (Porzig, 1982; Sladeczek et al., 1983; Staehelin et al., 1983). Therefore, the pres- ent investigation was undertaken to examine the interactions among ligand, receptor, and effector components in intact SH-SY5Y neural cells and their isolated membranes under identical experimental conditions, using both simple and physiological buffer media. The receptor binding of opioid agonist and antagonist, stimulation of low- $K_{\mathrm{m}}$ GTPase, and inhibition of adenylate cyclase were quantified. Preliminary findings of this work have been presented (Carter and Medzihradsky, 1990).

\section{MATERIALS AND METHODS}

\section{Materials}

The unlabeled opioids were obtained through the Narcotic Drug and Opioid Peptide Basic Research Center at the University of Michigan (Ann Arbor, MI, U.S.A.). [ ${ }^{3}$ H]DAMGO $(60 \mathrm{Ci} / \mathrm{mmol}),\left[\gamma^{32} \mathrm{P}\right] \mathrm{GTP}(30 \mathrm{Ci} / \mathrm{mmol})$, and the cyclic AMP (cAMP) assay kit were purchased from Amersham (Arlington Heights, IL, U.S.A.). $\left[{ }^{3} \mathrm{H}\right]$ Naltrexone was kindly provided by the National Institute on Drug Abuse. Dulbecco's modified Eagle's medium and fetal bovine serum were purchased from GIBCO Laboratories (Grand Island, NY, U.S.A.). Other biochemicals, including pertussis toxin, were obtained from Sigma Chemical Co. Human neuroblastoma SH-SY5Y cells, originating from Dr. June L. Biedler (Memorial Sloan-Kettering Cancer Center, New York, NY, U.S.A.), were a generous gift from Dr. S. K. Fisher (Department of Pharmacology, University of Michigan).

\section{Cell culture}

The SH-SY5Y cells (passage 79-85) were grown for 7-20 days in Dulbecco's modified Eagle's medium containing $10 \%$ fetal bovine serum, in tissue culture flasks or 35-mm-diameter polystyrene plates as described (Fisher and Snider, 1987). In all experiments with intact cells, their viability was ascertained by measuring the cellular $\mathrm{K}^{+} / \mathrm{Na}^{+}$ratio (Fischel and Medzihradsky, 1985). Under all experimental conditions a ratio of $\geq 3$ was obtained, indicative of intact cells with an unperturbed plasma membrane (Medzihradsky and Marks, 1975).

\section{Membrane isolation}

All experiments were carried out with freshly prepared membranes. The surface-growing cells were rinsed twice with phosphate-buffered saline (154 $\mathrm{mM} \mathrm{NaCl}, 0.61 \mathrm{~m} M$ $\mathrm{Na}_{2} \mathrm{HPO}_{4}$, and $0.38 \mathrm{mMKH} \mathrm{KO}_{4}, \mathrm{pH} 7.4$ ) and then removed from the flask surface by incubation with a $\mathrm{Ca}^{2+}, \mathrm{Mg}^{2+}$-free modified Puck's solution for $10 \mathrm{~min}$ (Honegger and Richelson, 1976). The suspension was centrifuged for $5 \mathrm{~min}$ at 200 $g$, and the pellet was suspended in hypotonic buffer $(0.61$ $\mathrm{mM} \mathrm{Na} \mathrm{HPO}_{4}, 0.38 \mathrm{~m} M \mathrm{KH}_{2} \mathrm{PO}_{4}, 0.2 \mathrm{mM} \mathrm{MgSO}_{4}$, and 1 $\mathrm{m} M$ dithiothreitol, $\mathrm{pH} \mathrm{7.4)}$ and gently dispersed in a Dounce homogenizer. This suspension was centrifuged for $15 \mathrm{~min}$ at $20,000 \mathrm{~g}$ and $4^{\circ} \mathrm{C}$, and the pellet was dispersed with the hypotonic buffer described above or with $50 \mathrm{~m} M$ Tris- $\mathrm{HCl}$ (pH 7.4) at a protein concentration of $1-2 \mathrm{mg} / \mathrm{ml}$.

For some experiments the cells were harvested into buffer A (128 m $M \mathrm{NaCl}, 2.4 \mathrm{~m} M \mathrm{KCl}, 2.0 \mathrm{~m} M \mathrm{NaHCO}_{3}, 3.0 \mathrm{~m} M$ $\mathrm{MgSO}_{4}, 10 \mathrm{mMNa} \mathrm{NPO}_{4}, 1.3 \mathrm{mMCaCl}, 10 \mathrm{mM}$ glucose, and $8 \mathrm{mM}$ theophylline, $\mathrm{pH} 7.4$ at $37^{\circ} \mathrm{C}$ ) and homogenized at a 1:100 dilution using a Brinkmann Polytron (model PT 10 ; setting of 6.5 ) for $1 \mathrm{~min}$. 


\section{Ligand binding}

Ligand binding in isolated membranes was carried out as described previously (Fischel and Medzihradsky, 1981; Clark et al., 1988). In brief, the assay medium contained $100 \mu \mathrm{l}$ of the membrane suspension (100-200 $\mu \mathrm{g}$ of protein), $300 \mu \mathrm{l}$ of buffer (either buffer A to give the final concentrations described above or $50 \mathrm{~m} M$ Tris-HCl, $\mathrm{pH}$ 7.4), $50 \mu \mathrm{l}$ of water (containing in some experiments $\mathrm{GTP}$ or $\mathrm{NaCl}$ to give final concentrations of $10 \mu M$ and $150 \mathrm{mM}$, respectively), $50 \mu \mathrm{l}$ of unlabeled opioid, and $25 \mu \mathrm{l}$ of radiolabeled ligand. Specific binding was determined with $20 \mu M$ DAMGO or $2 \mu M$ naltrexone, respectively, concentrations shown to give maximal displacement of the radioligands used. In displacement experiments $2 \mathrm{n} M\left[{ }^{3} \mathrm{H}\right]$ DAMGO or $0.5 \mathrm{n} M\left[{ }^{3} \mathrm{H}\right]$ naltrexone was used, whereas the concentration of unlabeled opioid varied. After a 15-min preincubation, the assay was initiated by addition of radiolabeled and unlabeled ligand. Following incubation to achieve ligand binding equilibrium at $37^{\circ} \mathrm{C}(80$ min for $\left[{ }^{3} \mathrm{H}\right]$ DAMGO, $30 \mathrm{~min}$ for $\left[{ }^{3} \mathrm{H}\right]$ naltrexone), the samples were quickly filtered and subjected to liquid scintillation counting as described.

For determination of ligand binding in intact cells, they were first rinsed with phosphate-buffered saline and lifted from the flask surface as described above. The cells were then pelleted $(5 \mathrm{~min}, 200 \mathrm{~g}$ ) and resuspended in buffer A at a protein concentration of $0.5 \mathrm{mg} / \mathrm{ml}$, corresponding to $\sim 2.4$ $\times 10^{6} \mathrm{cells} / \mathrm{ml}$. Aliquots $(400 \mu \mathrm{l})$ of this suspension were included in the receptor assay described above. In some experiments, before ligand binding the cells were exposed to pertussis toxin at $80 \mathrm{ng} / \mathrm{ml}$ of medium for 5 or $12 \mathrm{~h}$.

\section{Adenylate cyclase assay}

The assay of enzyme activity in isolated membranes was based on the procedure described by Olasmaa and Terenius (1988). In a final volume of $100 \mu$ l the assay medium contained $50 \mu \mathrm{l}$ of membrane suspension (40-70 $\mu \mathrm{g}$ of protein), $10 \mu \mathrm{l}$ of a mixture of GTP (final concentration, $10 \mu M$ ) and opioid ligand, and $40 \mu \mathrm{l}$ of buffer (final concentrations identical to those of buffer A with the addition of $1 \mathrm{mM}$ ATP and $1 \mathrm{~m} M$ ouabain). Creatine phosphate and creatine kinase were added fresh to the buffer medium to give final concentrations of $20 \mathrm{mM}$ and $3 \mathrm{U}$ per tube, respectively. The assay was initiated by addition of membranes to the prewarmed buffer medium and, after incubation for $10 \mathrm{~min}$ at $37^{\circ} \mathrm{C}$, was terminated by addition of $50 \mu \mathrm{l}$ of $0.15 \mathrm{M} \mathrm{HCl}$. At this point, the samples were frozen and kept at $-20^{\circ} \mathrm{C}$ until cAMP analysis. After thawing and neutralization with Tris base, aliquots were subjected to quantification of cAMP using a radioligand binding assay kit from Amersham.

For measurement of adenylate cyclase activity in intact cells, SH-SY5Y neurons grown to confluency in 35-mm-diameter plates were aspirated free of culture medium, rinsed three times with phosphate-buffered saline, and incubated for $30 \mathrm{~min}$ at $37^{\circ} \mathrm{C}$ in buffer A. Subsequently, the medium was replaced with $1.5 \mathrm{ml}$ of buffer A containing $43 \mu M$ prostaglandin $E_{2}$ (added to raise the level of CAMP and, thus, the sensitivity of the assay) with or without DAMGO. After 15 min at $37^{\circ} \mathrm{C}$, the reaction was terminated by aspiration of the buffer medium and addition of $1 \mathrm{ml}$ of $0.05 \mathrm{M} \mathrm{HCl}$. The cells were then scraped off the plates with $2 \mathrm{ml}$ of water and frozen at $-20^{\circ} \mathrm{C}$. After thawing, the suspension was centrifuged at $20,000 \mathrm{~g}$ for $15 \mathrm{~min}$, and the supernatant was neutralized with Tris base and subjected to quantification of cAMP using the Amersham kit. The remaining membrane pellets were dissolved in $1 M \mathrm{NaOH}$ for the determination of protein content.

\section{GTPase assay}

With minor modifications, the method described previously was used (Clark and Medzihradsky, 1987). In brief, the assay medium consisted of $30 \mu \mathrm{l}$ of membrane suspension, $40 \mu \mathrm{l}$ of the buffer described above for the adenylate cyclase assay (also containing 5'-adenylylimidodiphosphate to give a final concentration of $1 \mathrm{mM}$ ), $20 \mu \mathrm{l}$ of GTP solution (final concentration, $2 \mu M$; composed of $1.5 \mu M$ unlabeled and $\left.0.5 \mu M\left[\gamma \cdot{ }^{32} \mathrm{P}\right] \mathrm{GTP}\right)$, and $10 \mu \mathrm{l}$ of water or DAMGO solution. In separate tubes the opioid-insensitive, high- $K_{\mathrm{m}}$ GTPase activity was measured in the presence of $50 \mu M$ GTP. The assay was initiated by addition of membrane suspension to the prewarmed buffer medium. After incubation for $10 \mathrm{~min}$ at $37^{\circ} \mathrm{C}$, the liberated ${ }^{32} \mathrm{P}$ was separated from the nucleotide by charcoal treatment and subjected to liquid scintillation counting as described.

\section{Quantification of protein}

The method of Lowry et al. (1951) was used, with bovine serum albumin as the standard. For determination of the protein concentration in intact cells, the cell suspension was initially disrupted by sonication for $30 \mathrm{~s}$ (HeatsystemsUltrasonics; model W-385 with microtip; setting of 3.5), and the protein was solubilized with $0.2 M \mathrm{NaOH}$ for $1 \mathrm{~h}$ at $37^{\circ} \mathrm{C}$.

\section{Data analysis}

Homologous displacement and saturation data were fitted to a one- and two-site model with or without a linear binding component by nonlinear regression analysis using the NONLIN module of the computer program SYSTAT (Wilkinson, 1988). The results of multiple experiments were analyzed together, and all reported data are based on regressions for which the distribution of residuals was random and normal. The best fit to a given model was determined using the $F$ ratio test to compare the weighted residual sum of squares with $p>0.05$. The corresponding SEM was computed within NONLIN from the residual sum of squares of the regression. To account for variations in receptor density between different preparations of SH-SY5Y cells, an appropriate correction factor was calculated as described for the binding program LIGAND (Munson and Rodbard, 1980). The results of heterologous displacement were fitted to one- and two-site models using the computer program LIGAND. The parameters listed are those obtained from the best fit according to the $F$-ratio test where $p>0.05$ and for which a random, normal distribution of variance was observed.

Inhibition of adenylate cyclase and stimulation of low- $K_{\mathrm{m}}$ GTPase were expressed as $K_{\mathrm{i}}$ and $I_{\max }$ (maximal inhibition) and $K_{\mathrm{s}}$ (ligand concentration for half-maximal stimulation) and $S_{\max }$ (maximal stimulation), respectively. The data were subjected to nonlinear least squares analysis using the computer program GraphPad (ISI Software, Philadelphia, PA, U.S.A.). The values for $K_{\mathrm{i}}, I_{\max }, K_{\mathrm{s}}$, and $S_{\max }$ were determined by fitting all the data obtained from multiple experiments to a sigmoidal function: $Y=B /\left[1+\left(10^{x} / 10^{C}\right)^{D}\right]$, where $Y$ is the percent stimulation or inhibition, $X$ is the logarithm of the ligand concentration, $B$ is the maximum of the curve $\left(I_{\max }\right.$ or $\left.S_{\mathrm{max}}\right), C$ is the logarithm of ligand concentration at the half-maximum of the curve $\left(\log \mathrm{EC}_{50}, K_{\mathrm{i}}\right.$, or $\left.K_{\mathrm{s}}\right)$, and $D$ is the slope factor. 
TABLE 1. Parameters of ligand binding in whole cells

\begin{tabular}{|c|c|c|c|c|c|c|}
\hline \multirow[b]{2}{*}{ Experiment } & \multirow{2}{*}{$\begin{array}{c}\mathrm{T} \\
\left({ }^{\circ} \mathrm{C}\right)\end{array}$} & \multicolumn{2}{|c|}{$K_{\mathrm{D}}(\mathrm{n} M)$} & \multicolumn{2}{|c|}{$B_{\max }(\mathrm{fmol} / \mathrm{mg}$ of protein) } & \multirow[b]{2}{*}{$\mathbf{n}$} \\
\hline & & Site 1 & Site 2 & Site 1 & Site 2 & \\
\hline \multicolumn{7}{|l|}{$\left[{ }^{3} \mathrm{H}\right] \mathrm{DAMGO}$} \\
\hline Saturation & 37 & $2.5 \pm 0.7$ & ND & $25 \pm 3$ & ND & $62(5)$ \\
\hline Displacement & 37 & $3.9 \pm 1.4$ & $161 \pm 29$ & $34 \pm 9$ & $527 \pm 135$ & $86(4)$ \\
\hline Displacement & 4 & $10.2 \pm 4.4$ & $158 \pm 32$ & $37 \pm 17$ & $133 \pm 58$ & $67(3)$ \\
\hline \multicolumn{7}{|l|}{$\left[{ }^{3} \mathrm{H}\right]$ Naltrexone } \\
\hline Saturation & 37 & $1.1 \pm 0.1$ & ND & $252 \pm 7^{a}$ & ND & $36(3)$ \\
\hline Saturation & 4 & $0.3 \pm 0.04$ & ND & $361 \pm 18$ & ND & $20(2)$ \\
\hline
\end{tabular}

The parameters shown were obtained from nonlinear regression analysis using the program SYSTAT and considering binding models with one site, two sites, and one site and one linear binding component. The best fit was determined by comparison of the weighted residual sum of squares as described in Materials and Methods. Data are mean \pm SEM values from the number of observations indicated (no. of experiments). ND, not detected; $T$, temperature.

${ }^{a}$ Aspects to be considered in comparing receptor density in intact cells and isolated membranes as described in Results.

\section{RESULTS}

\section{Ligand binding in whole cells}

Saturation binding of $\left[{ }^{3} \mathrm{H}\right] \mathrm{DAMGO}$ at equilibrium depicted a single population of binding sites (Table 1), but homologous displacement of $\left[{ }^{3} \mathrm{H}\right] \mathrm{DAMGO}$ by high concentrations of the unlabeled opioid demonstrated biphasic ligand binding (Fig. 1 and Table 1). Saturation of the low-affinity sites with radiolabeled ligand was not feasible owing to high levels of nonspecific binding. In such cases, as shown previously with opioid receptor binding in brain slices (Barchfeld-Rothschild and Medzihradsky, 1985), homologous displacement (Fig. 1 , inset) offers an alternative to direct saturation binding. Various opioids, including both peptide and alkaloid agonists, were able to displace $>95 \%$ of specifically bound $\left[{ }^{3} \mathrm{H}\right] \mathrm{DAMGO}$, indicating the opioid nature of sites recognized by the peptide (Fig. 2 and Table 2 ). In addition, the high-affinity $K_{\mathrm{i}}$ for levorphanol was $\sim 2,000$-fold lower than that for its stereoisomer dextrorphan, demonstrating stereospecificity of the $\left[{ }^{3} \mathrm{H}\right] \mathrm{DAMGO}$ binding sites. Whereas the antagonist naltrexone displaced $\left[{ }^{3} \mathrm{H}\right] \mathrm{DAMGO}$ monophasically,

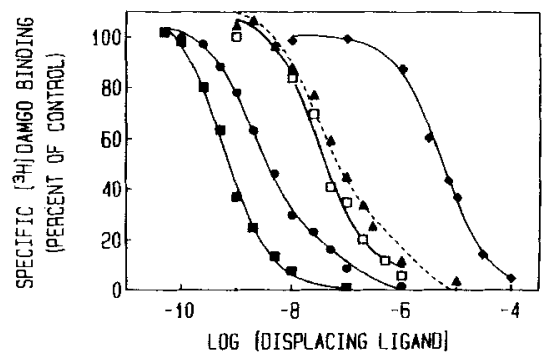

FIG. 2. Displacement of $\left[{ }^{3} \mathrm{H}\right] \mathrm{DAMGO}$ by opioids in intact cells. The inhibition of specific binding of $2 \mathrm{NM}\left[{ }^{3} \mathrm{H}\right.$ ]DAMGO in physiological buffer at $37^{\circ} \mathrm{C}$ by levorphanol ( $\bullet$ ), dextrorphan ( $\left.\uparrow\right)$, PL017 (A). naltrexone (D), and quaternary naltrexone (D) is shown. Data are mean values obtained in two to four experiments. The corresponding parameters and statistical information are listed in Table 2. displacement with the agonists levorphanol or PL017 was biphasic, suggesting receptor-G protein coupling (Fig. 2 and Table 2). Treatment of the cells with pertussis toxin for $5 \mathrm{~h}$ reduced, and for $12 \mathrm{~h}$ eliminated, high-affinity $\left[{ }^{3} \mathrm{H}\right] \mathrm{DAMGO}$ binding without altering the low-affinity component, whereby neither affinity was significantly altered by the toxin (Table 3 ). The toxin did not change the amount of antagonist binding, but rather altered the biphasic displacement of $\left[{ }^{3} \mathrm{H}\right]$ naltrexone by DAMGO: After treatment with pertussis toxin for $12 \mathrm{~h}$ only monophasic, low-affinity binding was detected (Table 3 ).

To investigate possible internalization of $\left[{ }^{3} \mathrm{H}\right]$ DAMGO, its displacement by quaternary naltrexone was assessed. This charged molecule does not penetrate biological membranes and should therefore only recognize binding sites on the cell surface (Valentino et al., 1981). Quaternary naltrexone displaced all specifically bound $\left[{ }^{3} \mathrm{H}\right] \mathrm{DAMGO}$ in intact SH-SY5Y cells

TABLE 2. Heterologous displacement of $\left.l^{3} H\right] D A M G O$ in whole cells

\begin{tabular}{lccc}
\hline & \multicolumn{2}{c}{$K_{\mathrm{i}}(\mathrm{n} M)$} & \\
\cline { 2 - 3 } \multicolumn{1}{c}{ Displacer } & Site 1 & Site 2 & $\mathrm{n}$ \\
\hline Levorphanol & $1.8 \pm 1.0$ & $43 \pm 37$ & $76(4)$ \\
Dextrorphan & $3,640 \pm 450$ & $\mathrm{ND}$ & $28(2)$ \\
PL017 & $31.0 \pm 12.3$ & $880 \pm 620$ & $74(4)$ \\
Naltrexone & $0.4 \pm 0.03$ & $\mathrm{ND}$ & $38(2)$ \\
Quaternary naltrexone & $29.3 \pm 5.0$ & $\mathrm{ND}$ & $34(2)$ \\
\hline
\end{tabular}

The parameters shown were obtained from nonlinear regression analysis using the program LIGAND and considering models with one and two sites. The best fit was determined on the basis of an $F$ ratio test as described in Materials and Methods. Data are mean \pm SEM values from the number of observations indicated (no, of experiments). ND, not detected.

${ }^{a}$ Tyr-Pro-(Me)Phe-D-Pro- $\mathrm{NH}_{2}$, a $\mu$-selective opioid (Chang et al., 1983). 
TABLE 3. Effects of pertussis toxin on ligand binding in whole cells

\begin{tabular}{|c|c|c|c|c|c|c|}
\hline \multirow{2}{*}{$\begin{array}{l}\text { Initial binding, } \\
\text { displacer }\end{array}$} & \multirow[b]{2}{*}{ Pertussis } & \multicolumn{2}{|c|}{$K_{\mathrm{D}}(\mathrm{n} M)$} & \multicolumn{2}{|c|}{$B_{\max }(\mathrm{fmol} / \mathrm{mg}$ of protein $)$} & \multirow[b]{2}{*}{$\mathbf{n}$} \\
\hline & & Site 1 & Site 2 & Site 1 & Site 2 & \\
\hline \multicolumn{7}{|l|}{$\left[{ }^{3} \mathrm{H}\right]$ DAMGO } \\
\hline DAMGO & - & $3.5 \pm 1.1$ & $118 \pm 77$ & $16 \pm 4.3$ & $99 \pm 38$ & $66(3)$ \\
\hline DAMGO & + & $2.3 \pm 3.0$ & $85 \pm 27$ & $3.4 \pm 3.2$ & $99 \pm 87$ & $56(3)$ \\
\hline \multicolumn{7}{|l|}{$\left[{ }^{3} \mathrm{H}\right]$ Naltrexone } \\
\hline DAMGO & - & $8.7 \pm 5.4$ & $420 \pm 130$ & $62 \pm 13$ & $125 \pm 12$ & $110(4)$ \\
\hline DAMGO & + & ND & $850 \pm 590$ & ND & $200 \pm 89$ & $56(2)$ \\
\hline
\end{tabular}

SH-SY5Y cells were incubated without $(-)$ and with $\left(+\right.$ ) pertussis toxin at $80 \mathrm{ng} / \mathrm{ml}$ of medium for $5 \mathrm{~h}$ (binding of [ ${ }^{3} \mathrm{H}$ ]DAMGO) or $12 \mathrm{~h}$ (binding of $\left[{ }^{3} \mathrm{H}\right]$ naltrexone). Subsequently, either homologous displacement of $\left[{ }^{3} \mathrm{H}\right] \mathrm{DAMGO}$ or displacement of $\left[{ }^{3} \mathrm{H}\right]$ naltrexone by DAMGO was carried out as described in Materials and Methods. The parameters shown were obtained from nonlinear regression analysis using the program SYSTAT (displacement of $\left[{ }^{3} \mathrm{H}\right] \mathrm{DAMGO}$ ) or LIGAND (displacement of $\left[{ }^{3} \mathrm{H}\right]$ naltrexone), considering binding models with one site or two sites with or without a linear component. The best fit was determined by comparison of the weighted residual sum of squares. Data are mean \pm SEM values from the number of observations indicated (no. of experiments). ND, not detected.

(Fig. 2). Cell surface binding of $\left[{ }^{3} \mathrm{H}\right] \mathrm{DAMGO}$ was further supported by experiments carried out at $4^{\circ} \mathrm{C}$ : Under these conditions $\left[{ }^{3} \mathrm{H}\right] \mathrm{DAMGO}$ still exhibited two binding components with similar parameters, except for the reduced $B_{\max }$ of the low-affinity site (Table 1 ).

In contrast to $\left[{ }^{3} \mathrm{H}\right] \mathrm{DAMGO}$, the opioid antagonist $\left[{ }^{3} \mathrm{H}\right]$ naltrexone bound to a single population of receptor sites (Fig. 1 and Table 1). Its $B_{\max }$ of $252 \mathrm{fmol} / \mathrm{mg}$ of protein corresponds to $\sim 32,000$ receptors per cell, in general agreement with the receptor density on the parent cell line, SK-N-SH (Yu et al., 1986). At $4^{\circ} \mathrm{C}$ the binding of $\left[{ }^{3} \mathrm{H}\right]$ naltrexone was also monophasic (Table 1 ).

\section{Ligand binding in isolated membranes}

Under conditions identical to those used in the experiments with intact cells, i.e., physiological medium at $37^{\circ} \mathrm{C},\left[{ }^{3} \mathrm{H}\right]$ DAMGO bound to a single site (Fig. 3 and Table 4). However, in contrast to whole cells, homologous ligand displacement failed to reveal additional low-affinity binding sites for $\left[{ }^{3} \mathrm{H}\right] \mathrm{DAMGO}$ : The data obtained best fit a single-site model, which corresponded well with the binding parameters of $\left[{ }^{3} \mathrm{H}\right]$ DAMGO obtained in saturation experiments ( Table 4). Whereas low temperature increased the $B_{\max }$ of [ $\left.{ }^{3} \mathrm{H}\right] \mathrm{DAMGO}$, addition of GTP reduced it by up to $87 \%$ without altering the best fit to a model of one population of sites (Fig. 3 and Table 4). To assess the influence of the physiological medium, opioid receptor binding of $\left[{ }^{3} \mathrm{H}\right]$ DAMGO was also determined in cell membranes suspended in Tris buffer. In this system both binding affinity and density of sites were higher than those obtained in the physiological medium (Fig. 3 and Table 4).

The main characteristics of $\left[{ }^{3} \mathrm{H}\right]$ naltrexone binding in membranes were the marginal effect of GTP, the increased binding affinity at $4^{\circ} \mathrm{C}$ [also observed with brain membranes (Fischel and Medzihradsky, 1981)], and the reduced $B_{\max }$ in physiological medium compared with that in Tris buffer (Fig. 3 and Table 4). It should be noted that the density of receptors in fragmented and intact cells is not directly comparable because ligand binding in cells was expressed on the basis of whole-cell protein. During membrane isolation $\sim 42 \%$ of cell protein was lost. Thus, the $B_{\max }$ of 252 $\mathrm{fmol} / \mathrm{mg}$ of whole-cell protein for $\left[{ }^{3} \mathrm{H}\right]$ naltrexone has to be corrected to $434 \mathrm{fmol} / \mathrm{mg}$ of membrane protein,

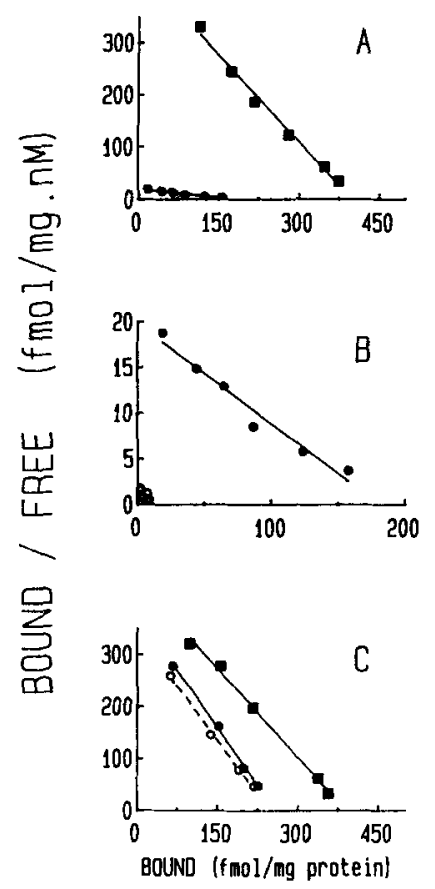

FIG. 3. Scatchard plots of opioid receptor binding in isolated SHSY5Y membranes. Results of saturation binding at equilibrium of (A and $\mathrm{B})\left[{ }^{3} \mathrm{H}\right] \mathrm{DAMGO}$ and $(\mathrm{C})\left[^{3} \mathrm{H}\right]$ naltrexone at $37^{\circ} \mathrm{C}$ in physiological medium (circles) or Tris- $\mathrm{HCl}(\mathrm{pH} \mathrm{7.4;} \mathrm{\Xi}$ ) in the presence (O) or absence (-) of $10 \mu M$ GTP are shown. Antagonist binding in Tris buffer was determined in the presence of $150 \mathrm{mM} \mathrm{NaCl}$. Representative experiments replicated two to five times are shown. The corresponding binding parameters and statistical information are listed in Table 4. 
TABLE 4. Parameters of opioid binding in isolated membranes

\begin{tabular}{|c|c|c|c|c|c|c|}
\hline Experiment & GTP & Buffer $^{a}$ & $\begin{array}{c}\mathrm{T} \\
\left({ }^{\circ} \mathrm{C}\right)\end{array}$ & $K_{\mathrm{D}}(\mathrm{n} M)$ & $\begin{array}{c}B_{\max } \\
\text { (fmol/mg of protein) }\end{array}$ & $\mathrm{n}$ \\
\hline \multicolumn{7}{|l|}{$\left[{ }^{3} \mathrm{H}\right]$ DAMGO } \\
\hline Saturation & - & A & 37 & $7.0 \pm 0.4$ & $142 \pm 4$ & $57(5)$ \\
\hline Displacement & - & A & 37 & $10.1 \pm 0.5$ & $201.2 \pm 5$ & $59(4)$ \\
\hline Saturation & + & A & 37 & $12.5 \pm 5.7$ & $18 \pm 9$ & $50(5)$ \\
\hline Displacement & + & A & 37 & $24.3 \pm 8.5$ & $69 \pm 25$ & $72(4)$ \\
\hline Displacement & - & A & 4 & $15.1 \pm 1.0$ & $470 \pm 16$ & $54(2)$ \\
\hline Saturation & - & Tris & 37 & $1.0 \pm 0.04$ & $469 \pm 7$ & $39(3)$ \\
\hline \multicolumn{7}{|l|}{$\left[{ }^{3} \mathbf{H}\right]$ Naltrexone } \\
\hline Saturation & - & A & 37 & $0.7 \pm 0.09$ & $299 \pm 16$ & $18(2)$ \\
\hline Saturation & + & A & 37 & $1.0 \pm 0.1$ & $348 \pm 17$ & $28(3)$ \\
\hline Saturation & - & A & 4 & $0.2 \pm 0.01$ & $330 \pm 3$ & $22(2)$ \\
\hline Saturation & - & Tris & 37 & $0.7 \pm 0.03$ & $449 \pm 9$ & $28(3)$ \\
\hline Saturation & - & Tris & 4 & $0.2 \pm 0.01$ & $431 \pm 9$ & $20(2)$ \\
\hline
\end{tabular}

The parameters shown were obtained from nonlinear regression analysis using the program SYSTAT and considering binding models with one site, two sites, and one site and one linear binding component. The best fit was determined by the $F$-ratio test as described in Materials and Methods. Some experiments were carried out in the presence of $10 \mu M$ GTP. Data are mean \pm SEM values from the number of observations indicated (no. of experiments). T, temperature.

${ }^{a}$ Buffer A denotes the physiological medium described in Materials and Methods, whereas Tris refers to $50 \mathrm{~m} M$ Tris- $\mathrm{HCl}, \mathrm{pH} 7.4$.

in agreement with the value of $450 \mathrm{fmol} / \mathrm{mg}$ determined.

\section{Receptor-effector coupling in whole cells}

As shown in Fig. 4, DAMGO inhibited the prostaglandin $\mathrm{E}_{2}$-stimulated formation of cAMP with a $K_{\mathrm{i}}$ of $11.2 \pm 2.9 \mathrm{n} M$ and $I_{\max }$ of $33.1 \pm 2.0 \%$ (mean \pm SEM, $\mathrm{n}=7$ ). The inhibition was mediated by the $\mu$-opioid receptor: The effect was blocked by $10 \mu M$ naloxone but not by the same concentrations of the $\delta$-selective antagonist ICI-174,864 (data not shown).

\section{Receptor-effector coupling in isolated membranes}

In cell membranes suspended in physiological medium the characteristics of adenylate cyclase inhibition by DAMGO were similar to those observed in intact cells, with values (mean $\pm \mathrm{SEM}, \mathrm{n}=6$ ) for $K_{\mathrm{i}}$ and $I_{\max }$ of $25.8 \pm 4.8 \mathrm{n} M$ and $27 \pm 1.0 \%$, respectively (Fig. 4). In addition, DAMGO stimulated low- $K_{\mathrm{m}}$ GTPase activity with an $S_{\max }( \pm \mathrm{SEM}, \mathrm{n}=4)$ of $47.6 \pm 3.8 \%$ and a $K_{\mathrm{s}}$ of $31.5 \pm 8.6 \mathrm{n} M$, a value quite similar to the $K_{\mathrm{i}}$ for inhibition of adenylate cyclase. Both opioid-stimulated GTPase activity and the inhibition of adenylate cyclase were completely inhibited by $10 \mu M$ naloxone but were insensitive to ICI-174,864.

The efficiency of receptor-effector coupling was dependent on the mode of membrane isolation. In the experiments described above the membranes were obtained by hypotonic lysis of the cells, followed by a gentle dispersion in a Dounce homogenizer, and were used immediately. However, if the cells were homogenized in a Brinkmann Polytron, the $K_{5}$ for GTPase stimulation by DAMGO increased to $98.8 \pm 6.5 \mathrm{nM}$ (mean $\pm \mathrm{SEM}, \mathrm{n}=6$ ), at similar $S_{\max }$. Furthermore, such vigorous treatment reduced the opioid receptormediated inhibition of adenylate cyclase to $<10 \%$. The harsh homogenization of cells primarily affected receptor-effector coupling because the basal activity of adenylate cyclase following either treatment was unchanged: $30.2 \pm 7.3 \mathrm{pmol}$ of $\mathrm{cAMP} / \mathrm{min} / \mathrm{mg}$ of protein in hypotonic lysates and $29.5 \pm 6.5 \mathrm{pmol}$ of cAMP/ $\mathrm{min} / \mathrm{mg}$ of protein in Polytron-disrupted membranes.

\section{DISCUSSION}

Although direct saturation binding of $\left[{ }^{3} \mathrm{H}\right] \mathrm{DAMGO}$ in intact SH-SY5Y cells indicated the presence of a single population of sites with high affinity, both homologous and heterologous displacement of the radioligand by higher concentrations of opioid agonists revealed additional sites of lower affinity. In contrast, the opioid antagonist naltrexone bound to a single population of sites, and its displacement of bound $\left[{ }^{3} \mathrm{H}\right]$ DAMGO was monophasic. This differential resolution of $\left[{ }^{3} \mathrm{H}\right]$ DAMGO binding by opioid agonists and antagonists suggests the involvement of receptor$\mathrm{G}$ protein coupling as the underlying mechanism. It has recently been shown that high-affinity opioid agonist binding in brain membranes reflects the ligandoccupied receptor-G protein complex (Remmers and Medzihradsky, 1991a). The presence in intact cells of $\mathrm{G}$ protein-coupled and -uncoupled $\mu$-opioid receptors was strongly supported by experiments with pertussis toxin, which uncouples the receptor by catalyzing the covalent modification of $\mathrm{G}_{\mathrm{i}}$ inhibitory $\mathrm{G}$ proteins $(\mathrm{Ku}$ rose et al., 1983). Treatment of the cells with the toxin for $5 \mathrm{~h}$ reduced high-affinity agonist binding by $80 \%$. Furthermore, in cells exposed to the toxin for $12 \mathrm{~h}$ the biphasic displacement of $\left[{ }^{3} \mathrm{H}\right]$ naltrexone by DAMGO became monophasic, representing a shift from highto low-affinity binding, whereby antagonist bind- 


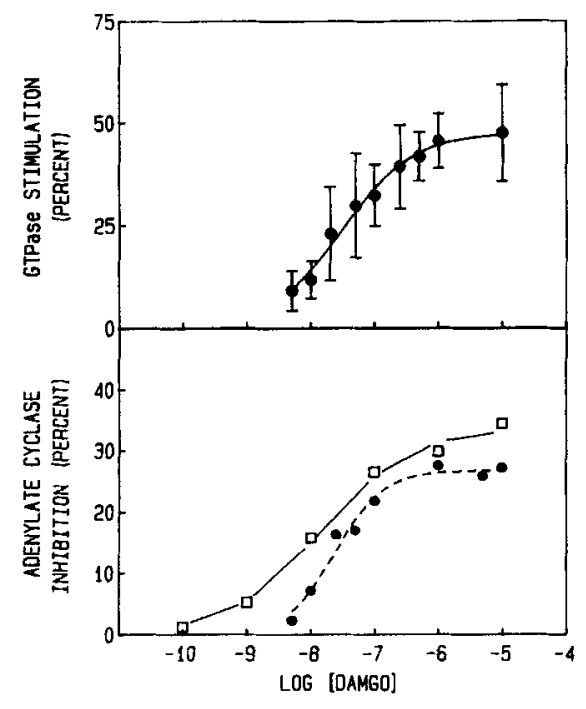

FIG. 4. Receptor-effector coupling in intact and fragmented SHSY5Y cells. DAMGO stimulation of low- $K_{m}$ GTPase in cell lysates (upper panel) and inhibition of adenylate cyclase (lower panel) in lysates $(\Theta)$ and intact cells $(\square)$, all suspended in physiological buffer at $37^{\circ} \mathrm{C}$, are shown. Data are mean \pm SEM (bars) values (where indicated) from four to seven experiments. The curves were drawn according to nonlinear regression analysis as described in Materials and Methods, and the parameters describing the curves are listed in Results.

ing remained unaltered. The biphasic binding of $\left[{ }^{3} \mathrm{H}\right] \mathrm{DAMGO}$ in intact cells at $4^{\circ} \mathrm{C}$, carried out to inhibit endocytosis, and its complete displacement by quaternary naltrexone provided evidence against ligand internalization as an involved process. The recent report of DAMGO binding to one site in SH-SY $5 Y$ cells (Toll, 1990) might be the result of using ligand concentrations that were too narrow to discern two affinity states with widely diverging $K_{\mathrm{D}}$ values.

In isolated SH-SY5Y membranes suspended in physiological medium at $\left.37^{\circ} \mathrm{C},{ }^{3} \mathrm{H}\right]$ DAMGO bound to a single population of sites with a $K_{\mathrm{D}}$ similar to that of the high-affinity site observed in intact cells. Because low-affinity agonist binding represents interaction with the uncoupled form of the receptor brought about by GTP and its nonhydrolyzable analogues (Remmers and Medzihradsky, 1991a), the removal of guanine nucleotides during membrane isolation is likely to shift the receptors largely into a coupled, high-affinity state. Indeed, the addition of GTP to membranes strongly reduced the binding of $\left[{ }^{3} \mathrm{H}\right] \mathrm{DAMGO}$. In membranes suspended in Tris buffer such attenuation of opioid agonist binding by GTP is much less pronounced (Kazmi and Mishra, 1987). Apparently, the effect of guanine nucleotides on opioid receptor binding in a physiological buffer medium reflects the modulation occurring in whole cells. Although the binding of $\left[{ }^{3} \mathrm{H}\right]$ DAMGO in the presence of GTP had a significant linear component, the data could not be adequately fitted to a two-site model. This may indicate the presence of low-affinity sites that are below the limit of detection owing to increasing nonspecific binding at high ligand concentration. Such sites, however, would have to have an affinity below that seen in cells. As expected, binding of $\left[{ }^{3} \mathrm{H}\right]$ naltrexone was unaltered by GTP, and its high $B_{\max }$ indicated that some of the receptor sites recognized by the antagonist were undetected by $\left[{ }^{3} \mathrm{H}\right]$ DAMGO. In rat brain membranes, the equilibrium binding of $\left[{ }^{3} \mathrm{H}\right]$ naltrexone yields biphasic Scatchard plots (see, e.g., Fischel and Medzihradsky, 1981). It has recently been shown that the low-affinity component of that binding reflects the interaction of naltrexone with $\delta$-opioid receptors (Remmers and Medzihradsky, 1991b). Because the majority of opioid receptors on the SH-SY5Y cells are the $\mu$ type (Yu and Sadee, 1988), low-affinity binding to $\delta$ receptors was undetectable below $15 \mathrm{n} M$, the highest concentration of $\left[{ }^{3} \mathrm{H}\right]$ naltrexone used in the saturation experiments.

In the physiological medium the properties of opioid ligand binding were quite different from those obtained in Tris buffer. Whereas a decrease in binding affinity was limited to [ $\left.{ }^{3} \mathrm{H}\right] \mathrm{DAMGO}$, attenuation of $B_{\max }$ was also observed for $\left[{ }^{3} \mathrm{H}\right]$ naltrexone. Apparently the extracellular ionic milieu, resembling that in vivo, modulates opioid binding by reducing the number of available receptor sites as the result of divalent cation action (Paterson et al., 1986) and by decreasing the affinity of agonist binding to the antagonist receptor conformation prevailing in the presence of sodium (Pert and Snyder, 1974; Nijssen and Childers, 1987). In the course of assessing the influence of temperature on opioid binding, it was observed that in isolated membranes, suspended in physiological buffer at $4^{\circ} \mathrm{C}$, the $B_{\max }$ of $\left.{ }^{3} \mathrm{H}\right] \mathrm{DAMGO}$ was increased relative to that determined at $37^{\circ} \mathrm{C}$. The measured receptor density of $470 \mathrm{fmol} / \mathrm{mg}$ of protein agrees remarkably well with that seen with $\left[{ }^{3} \mathrm{H}\right] D A M G O$ at $37^{\circ} \mathrm{C}$ in Tris buffer and with $\left[{ }^{3} \mathrm{H}\right]$ naltrexone in Tris buffer plus sodium at 37 and $4^{\circ} \mathrm{C}$. This effect may reflect enhanced opioid receptor coupling to $\mathrm{G}$ protein in the physiological medium at $4^{\circ} \mathrm{C}$, resulting in increased high-affinity agonist binding and an elevated $B_{\max }$ for $\left[{ }^{3} \mathrm{H}\right] D A M G O$. Facilitated receptor-G protein coupling at low temperatures has been reported for the muscarinic receptor (Aronstam and Narayanan, 1988).

Of particular significance for this investigation was the concurrent assessment of three components of the opioid receptor-effector system under identical experimental conditions, i.e., ligand binding and receptor coupling to $\mathrm{G}$ protein and adenylate cyclase.

The functional assays indicated that, in contrast to other cellular systems (Costa et al., 1988), the efficiency of receptor coupling to adenylate cyclase can be quite similar in whole cells and isolated membranes. However, the coupling mechanism was found to be very sensitive to the method of membrane isolation, an observation that may account for some of the reported disparities in the characteristics of receptor-effector coupling. A quantitative assessment of the latter process 
is obtained by comparing receptor binding affinity with the ligand concentration required to produce halfmaximal effector response, i.e., $K_{\mathrm{D}} / K_{\mathrm{i}}$ for adenylate cyclase or $K_{\mathrm{D}} / K_{\mathrm{s}}$ for low- $K_{\mathrm{m}}$ GTPase. The $K_{\mathrm{D}} / K_{\mathrm{i}}$ ratio in intact SH-SY5Y cells (considering the high-affinity $K_{\mathrm{D}}$ ) was 0.35 . Using the appropriate constants for isolated membranes virtually the same ratio is obtained. Furthermore, the ratio of $K_{\mathrm{D}} / K_{\mathrm{s}}$ was also 0.32 . These relationships indicate that in SH-SY5Y cells, signal transduction from the opioid receptor via $G$ protein to adenylate cyclase is similar and of relatively low efficiency. However, if the low-affinity $K_{\mathrm{D}}$ is considered, a ratio of 14 is obtained, indicative of a receptor reserve. To achieve a half-maximal effector response for either cells or their lysates, $\sim 70 \%$ of the opioid receptors in the high-affinity state must be occupied. For the coupling of opioid receptors to both $G$ protein (Clark et al., 1989) and adenylate cyclase (Fantozzi et al., 1981), a large receptor reserve was described. In membrane binding assays without GTP, most of the receptors are in the high-affinity, coupled state. In contrast, in functional assays requiring GTP and $\mathrm{Na}^{+}$(Blume et al., 1979), the receptors will be predominantly in an uncoupled state. The findings presented here indicate that under conditions that mimic those in vivo, i.e., intact cells, or membranes in physiological medium with GTP, only a small fraction of the receptor population is coupling to the investigated effectors, and thus most of the receptors are nonfunctional or "spare."

Acknowledgment: The authors are grateful to Dr. G. L. Nordby for his advice on the statistical treatment of the data. The expert secretarial assistance of Ms. B. McLaughlin is acknowledged. This work was supported by U.S. Public Health grant DA 04087.

\section{REFERENCES}

Aronstam R. S. and Narayanan T. K. (1988) Temperature effect on the detection of muscarinic receptor- $G$ protein interactions in ligand binding assays. Biochem. Pharmacol. 37, 1045-1049.

Barchfeld C. C. and Medzihradsky F. (1984) Receptor-mediated stimulation of brain GTPase by opiates in normal and dependent rats. Biochem. Biophys. Res. Commun. 121, 641-648.

Barchfeld-Rothschild C. C. and Medzihradsky F. (1985) Heterogeneity of opioid receptor binding in brain slices. J. Neurosci. Res. 18, 358-365.

Blanchard S. G., Chang K.-J., and Cuatrecasas P. (1983) Characterization of the association of tritiated enkephalin with neuroblastoma cells under conditions optimal for receptor down regulation. J. Biol. Chem. 258, 1092-1097.

Blume A. J., Lichtshtein D., and Boone G. (1979) Coupling of opiate receptors to adenylate cyclase: requirement for $\mathrm{Na}^{+}$and GTP. Proc. Natl. Acad. Sci. USA 76, 5626-5630.

Burns D. L., Hewelett E., Moss J., and Vaughan M. (1983) Pertussis toxin inhibits enkephalin stimulation of GTPase in NG108-15 cells. J. Biol. Chem. 258, 1435-1438.

Carroll J. A., Shaw J. S., and Wickenden A. D. (1988) The physiological relevance of low agonist affinity binding at $\mu$-receptors. Br. J. Pharmacol. 94, 625-631.

Carter B. D. and Medzihradsky F. (1990) Opioid receptor binding and receptor-effector coupling in intact neurons and their isolated membranes. Eur. J. Pharmacol. 183, 1744-1745.

Chang K.-J., Wei E. T., Killian A., and Chang J.-K. (1983) Potent morphiceptin analogs: structure-activity relationships and morphine-like activities. J. Pharmacol. Exp. Ther. 227, 403-408.

Clark M. J. and Medzihradsky F. (1987) Coupling of multiple opioid receptors to GTPase following selective receptor alkylation in brain membranes. Neuropharmacology 26, 1763-1770.

Clark M. J., Carter B. D., and Medzihradsky F. (1988) Selectivity of ligand binding to opioid receptors in brain membranes from the rat, monkey and guinea pig. Eur. J. Pharmacol. 148, 343-351.

Clark M. J., Nordby G. L., and Medzihradsky F. (1989) Relationship between opioid-receptor occupancy and stimulation of low- $K_{\mathrm{m}}$ GTPase in brain membranes. J. Neurochem. 52, 1162-1169.

Costa T., Wuster M., Gramsch C., and Herz A. (1985) Multiple states of opioid receptors may modulate adenylate cyclase in intact neuroblastoma $\times$ glioma hybrid cells. Mol. Pharmacol. 28, 146154.

Costa T., Klinz F., Vachon L., and Herz A. (1988) Opioid receptors are coupled tightly to $\mathrm{G}$ proteins but loosely to adenylate cyclase in NG108-15 cell membranes. Mol. Pharmacol. 34, 744-754.

Creese I. and Snyder S. H. (1975) Receptor binding and pharmacological activity of opiates in the guinea-pig intestine. J. Pharmacol. Exp. Ther. 194, 205-219.

Fantozzi R., Mullikin-Kilpatrick D., and Blume A. J. (1981) Irreversible inactivation of the opiate receptors in the neuroblastoma $\times$ glioma hybrid NG108-15 by chlornaltrexamine. Mol. Pharmacol. 20, 8-15.

Fischel S. V. and Medzihradsky F. (1981) Scatchard analysis of opiate receptor binding. Mol. Pharmacol. 20, 269-279.

Fischel S. V. and Medzihradsky F. (1985) Assessment of membrane permeability in primary cultures of neurons and glia in response to osmotic perturbation. J. Neurosci. Res. 13, 369-380.

Fisher S. K. and Snider R. M. (1987) Differential receptor occupancy requirements for muscarinic cholinergic stimulation of lipid hydrolysis in brain and in neuroblastomas. Mol. Pharmacol. 32, $81-90$.

Honegger P. and Richelson E. (1976) Biochemical differentiation of mechanically dissociated mammalian brain in aggregating cell culture. Brain Res. 109, 335-354.

Kazmi S. M. I. and Mishra R. K. (1987) Comparative pharmacological properties and functional coupling of $\mu$ and $\delta$ opioid receptor sites in human neuroblastoma SH-SY5Y cells. Mol. Pharmacol. 32, 109-118.

Koski G. and Klee W. A. (1981) Opiates inhibit adenylate cyclase by stimulating GTP hydrolysis. Proc. Natl. Acad. Sci. USA 78, 4185-4189.

Kurose H., Katada T., Amano T., and Ui M. (1983) Specific uncoupling by islet-activating protein, pertussis toxin, of negative signal transduction via $\alpha$-adrenergic, cholinergic, and opiate receptors in neuroblastoma $\times$ glioma hybrid cells. J. Biol. Chem. 258, $4870-4875$.

Law P. Y., Wu J., Koehler J. E., and Loh H. H. (1981) Demonstration and characterization of opiate inhibition of the striatal adenylate cyclase. $J$. Neurochem. 36, 1834-1846.

Law P. Y., Hom D. S., and Loh H. H. (1983) Opiate regulation of adenosine $3^{\prime}: 5^{\prime}$-cyclic monophosphate level in neuroblastoma $\times$ glioma NG108-15 hybrid cells. Relationship between receptor occupancy and effect. Mol. Pharmacol. 23, 26-35.

Lowry O. H., Rosebrough N. J., Farr A. L., and Randall R. J. (1951) Protein measurement with the Folin phenol reagent. J. Biol. Chem. 193, 265-275.

Medzihradsky F. and Marks M. J. (1975) Measures of cell viability. Biochem. Med. 13, 164-177.

Munson P. J. and Rodbard D. (1980) LIGAND: a versatile approach for characterization of ligand-binding systems. Anal. Biochem. 107, 220-239.

Nijssen P. C. G. and Childers S. R. (1987) Characteristics of sodiuminduced increase in opiate antagonist binding sites in rat brain membranes. Eur. J. Pharmacol. 135, 355-364.

Olasmaa M. and Terenius L. (1988) Prolonged exposure of human neuroblastoma SH-SY5Y cell line to morphine and oxotremorine modulates signal transduction in adenylate cyclase system. Brain Res. 475, 291-296. 
Paterson S. J.. Robson L. E., and Kosterlitz H. W. (1986) Control by cations of opioid binding in guinea pig brain membranes. Proc. Natl. Acad. Sci. USA 83, 6216-6220.

Pert C. B. and Snyder S. H. (1974) Opiate receptor binding of agonists and antagonists affected differentially by sodium. Mol. Pharmacol. 10, 868-879.

Porzig H. (1982) Are there differences in the $\beta$-receptor-adenylate cyclase systems of fragmented and living cells? in More About Receptors (Lamble J. W., ed), pp. 25-31. Elsevier, New York.

Puttfarcken P., Werling L. L., Brown S. R., Cote T. E., and Cox B. M. (1986) Sodium regulation of agonist binding at opioid receptors. I. Effects of sodium replacement on binding at $\mu$-and $\delta$-type receptors in $7315 \mathrm{c}$ and NG108-15 cells and cell membranes. Mol. Pharmacol. 30, 81-89.

Remmers A. E. and Medzihradsky F. (1991a) Reconstitution of highaffinity opioid agonist binding in brain membranes. Proc. Natl. Acad. Sci. USA 88, 2171-2175.

Remmers A. E. and Medzihradsky F. (1991b) Resolution of biphasic binding of the opioid antagonist naltrexone in brain membranes. J. Neurochem. 57, 1265-1269.

Roth B. L., Laskowski M. B., and Coscia C. J. (1981) Evidence for distinct subcellular sites of opiate receptors. Demonstration of opiate receptors in smooth microsomal fractions isolated from rat brain. J. Biol. Chem. 256, 10117-10123.

Schweigerer L., Schmidt W., Teschemacher H., and Gramsch C. (1985) $\beta$-Endorphin: surface binding and internalization in thymoma cells. Proc. Natl. Acad. Sci. USA 82, 5751-5755.

Sharma S. D., Nirenberg M., and Klee W. A. (1975) Morphine re- ceptors as regulators of adenylate cyclase activity. Proc. Natl. Acad. Sci. USA 72, 590-594.

Sladeczek F., Bockaert J., and Mauger J. (1983) Differences between agonist and antagonist binding to $\alpha$-1-adrenergic receptors of intact and broken-cell preparations. Mol. Pharmacol. 24, 392397.

Staehelin M., Simons P., Jaegg K., and Wigger N. (1983) CGP-12177. A hydrophilic $\beta$-adrenergic receptor radioligand reveals high affinity binding of agonists to intact cells. J. Biol. Chem. 258, 3496-3502.

Toll L. (1990) $\mu$-Opioid receptor binding in intact SH-SY5Y neuroblastoma cells. Eur. J. Pharmacol. 176, 213-217.

Valentino R. J., Herling S., Woods J. H., Medzihradsky F., and Merz H. (1981) Quaternary naltrexone; evidence for the central mediation of discriminative stimulus effects of narcotic agonists and antagonists. J. Pharmacol. Exp. Ther. 217, 652-659.

Werling L. L., Zarr G. D., Brown S. R., and Cox B. M. (1985) Opioid binding to rat and guinea-pig neural membranes in the presence of physiological cations at $37^{\circ} \mathrm{C} . J$. Pharmacol. Exp. Ther. 233, $722-728$.

Wilkinson L. (1988) SYSTAT: The System for Statistics. SYSTAT, Evanston, Illinois.

Yu V. C. and Sadée W. (1988) Efficacy and tolerance of narcotic analgesics at the $\mu$ opioid receptor in differentiated human neuroblastoma cells. J. Pharmacol. Exp. Ther. 245, 350-355.

Yu V. C., Richards M. L., and Sadée W. (1986) A human neuroblastoma cell line expresses $\mu$ and $\delta$ opioid receptor sites. J. Biol. Chem. 261, 1065-1070. 